EJIM

25,6

Received 14 September 2020 Revised 10 February 2021 Accepted 19 March 2021

\section{The nexus between dynamic capabilities and competitive firm performance: the mediating role of open innovation}

\author{
Asta Pundziene \\ School of Economics and Business, Kaunas University of Technology, \\ Kaunas, Lithuania \\ Shahrokh Nikou \\ Information Studies, Åbo Akademi University, Turku, Finland and \\ Stockholm University, Stockholm, Sweden, and \\ Harry Bouwman \\ Section of Information and Communication Technology, \\ Delft University of Technology, Delft, The Netherlands
}

\begin{abstract}
Purpose - Prior research has reported the indirect implications of firm's dynamic capabilities on their competitive firm performance. Our attention now turns to open innovation since it has been confirmed to be an influential factor contributing to the superior performance of technological firms. So far there has been little research on assessing the relationship between a firm's dynamic capabilities as an antecedent of the competitive performance of the firm or investigations into the mediating role of open innovation in this relationship.
\end{abstract}

Design/methodology/approach - Drawing on the theory of dynamic capabilities, we developed a framework as a way to better understand the role of open innovation, which could then help to better explain the relationship between firms' dynamics capabilities and their competitive firm performance. Based on the empirical data of 465 firms operating in innovative and non-innovative industries, we employed structural equation modelling (SEM) to examine the research hypotheses and the path relationships in the proposed model.

Findings - The SEM analysis revealed that a firm's dynamic capabilities significantly impact its open innovation performance and that open innovation, consequently, impacts the competitive performance of the firm. Moreover, the results show that the path between dynamic capabilities and competitive firm performance is partially mediated through open innovation.

Practical implications - The findings provide practical implications and draw managerial attention to the importance of: (1) investing in innovation, (2) engaging customers in the innovation process and (3) maintaining innovation management excellence as significant antecedent factors in increasing competitive firm performance.

Originality/value - Considering the lack of empirical research in the literature on the links between dynamic capabilities and open innovation, this paper contributes to the dynamic capabilities and open innovation literature by confirming that open innovation not only mediates the relationship between these two aspects but also strengthens the effect the dynamic capabilities have on competitive firm performance. Besides, due to the

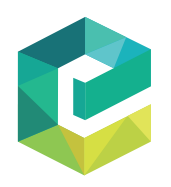

European Journal of Innovation Management Vol. 25 No. 6, 2022 pp. $152-177$ Emerald Publishing Limited $1460-1060$

DOI 10.1108/EJIM-09-2020-0356
(C) Asta Pundziene, Shahrokh Nikou and Harry Bouwman. Published by Emerald Publishing Limited. This article is published under the Creative Commons Attribution (CC BY 4.0) licence. Anyone may reproduce, distribute, translate and create derivative works of this article (for both commercial and noncommercial purposes), subject to full attribution to the original publication and authors. The full terms of this licence may be seen at http://creativecommons.org/licences/by/4.0/legalcode

This project has received funding from the European Social Fund (project No. K71208006) under a grant agreement with the Research Council of Lithuania (LMTLT). 
significant impact of dynamic capabilities on open innovation, dynamic capabilities might be regarded as an antecedent of open innovation.

Keywords Open innovation, Dynamic capabilities, Firm performance, Antecedents, Mediating role Paper type Research paper

\section{Introduction}

Despite the growing body of research on dynamic capabilities and competitive firm performance, there is no clear answer as to why firms still fail. Teece (2014) noted that the dynamic capabilities view was created as a general framework to aggregate the knowledge of firm-level competitive advantage under the conditions of strong innovation-driven and often global competition. Dynamic capabilities indicate a firm's ability to integrate, build and reconfigure its internal and external competences to address rapidly changing business environments (Teece et al., 1997, p. 516). Since 2003, several empirical studies have examined and tested the impact of dynamic capabilities on competitive firm performance (e.g. Arthurs and Busenitz, 2006; Bitencourt et al., 2020; Drnevich and Kriauciunas, 2011; Hung et al., 2010; Janssen et al., 2016; Jantunen et al., 2005; Karna et al., 2015; Li and Liu, 2014; Macher and Mowery, 2009; Malik and Kotabe, 2009; Protogerou et al., 2012; Ringov, 2017; Schilke, 2014; Wang et al., 2015a, b; Wilden et al., 2016; Wu, 2007;Zott, 2003). At the same time, other authors have attempted to provide conceptual insights into the relationship between dynamic capabilities and competitive firm performance (e.g. Augier and Teece, 2009; Helfat and Peteraf, 2009; Prange and Verdier, 2011; Teece, 2007; Wang and Ahmed, 2007). As a result, to date, the dominant position of scholars is that a firm's dynamic capabilities have a significant impact on its performance; however, the impact is indirect.

There have been several different attempts to explain the indirect effect of dynamic capabilities on firm performance. As such, some scholars (e.g. Eisenhardt and Martin, 2000; Protogerou et al., 2012; Wilden et al., 2016) have suggested that dynamic capabilities create value through reconfiguring operational capabilities and thus the impact of a firm's dynamic capabilities on firm performance is mediated by the firm's operational capabilities. Operational capabilities are defined as "corporate and business unit mechanisms that affect firm strategy and performance" (Wilden et al., 2016, p. 1033). While open innovation might be considered as one of these, the possibility of its mediating role in the relationship between dynamic capabilities and firm performance has so far been neglected in the literature. Bogers et al. (2019, p. 84) stated that all three organisational processes of dynamic capabilities - sensing, seizing and transforming - can help firms to effectively reap the full benefits of "open innovation". Furthermore, Teece (2020, pp. 12-14) stated that "open innovation is a natural fit with the dynamic capabilities framework" and "strong dynamic capabilities will increase the effectiveness of open innovation efforts". While the significant interlinkages between dynamic capabilities and open innovation have recently been conceptually acknowledged, there is still a lack of empirical research that has attempted to examine and establish the mediating role of open innovation in the relationship between dynamic capabilities and firm performance.

Open innovation is defined as a distributed innovation process incorporating managed knowledge flows across organisational boundaries, using different mechanisms in line with the firm's business model (Chesbrough and Bogers, 2014). Moreover, open innovation allows a firm to combine both internal and external knowledge into its organisational architecture and systems, the requirements of which are defined by its business model and, thus, its plan to drive and sustain innovation (Fortunato et al., 2017, p. 239). Inside-out and outside-in innovation processes are the fundamental aspects of an open innovation strategy (Natalicchio et al., 2014, p. 66), using different mechanisms in line with the firm's business model to accelerate internal innovation and to reinforce the firm's competitiveness (Chesbrough and Bogers, 2014). The main idea of open innovation is to open up the innovation process to
Dynamic
capabilities and competitive firm performance

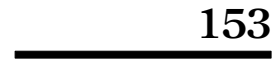


EJIM

25,6

external resources (e.g. firms, individuals, suppliers) to facilitate the smooth flow of knowledge inside and outside the firm (Simeone et al., 2020, p. 1821). Furthermore, Randhawa et al. (2016), following an analysis of 321 journal articles on open innovation, concluded that the dynamic capabilities perspective is underutilised in open innovation research. The authors encouraged both open innovation and strategic management scholars to develop hypotheses around the under-researched effect of dynamic capabilities on open innovation and competitive firm performance.

Therefore, this research aimed to empirically examine if dynamic capabilities affect open innovation and, in turn, whether the relationship between dynamic capabilities and firm performance is mediated through open innovation (Bogers et al., 2019; Ferreira et al., 2020; Kitenga et al., 2020; Teece et al., 2020; Teece, 2020). In doing so and given the importance of the research at hand, the present study utilised and extends the existing dynamic capabilities and open innovation theories to explicate the link between dynamic capabilities, open innovation and competitive firm performance. From a theoretical perspective, this paper extends our comprehension and sheds new light on the mechanism that facilitates the impact of dynamic capabilities on competitive firm performance by exploring the mediating effect of open innovation on this relationship. Ultimately, the research question, this paper addresses is as follows: What is the role of open innovation in the pathway between dynamic capabilities and competitive firm performance? We answer the question by leveraging the empirical data of 465 firms and by applying structural equation modelling (SEM).

By answering the research question, this paper extends the dynamic capabilities and open innovation literature in the following manner. First, we address the so far neglected theoretical gap on empirically testing the relationship between dynamic capabilities and firm performance and on examining the mediating role of open innovation in this path relationship. By doing so, we empirically confirm the theoretical notion that dynamic capabilities and open innovation are closely interlinked; moreover that dynamic capabilities create value through integrating and recombining open innovation processes. Thus, dynamic capabilities might be regarded as antecedents of open innovation. Second, our findings contribute to the open innovation research by providing evidence that open innovation has a positive implication on competitive firm performance. Moreover, we extend the knowledge about open innovation's effect on competitive firm performance by showing that open innovation serves as a mediator that reinforces the effect of a firm's dynamic capabilities on its competitive firm performance. Third, we add a new component of open innovation - inside-in open innovation - and show how inside-in complements outside-in and inside-out with an internal focus of the open innovation processes. Fourth, the research results add to the knowledge of firm managers on how to pursue competitive firm performance by strengthening their dynamic capabilities and deploying open innovation processes. Additionally, we show that special attention should be paid to engaging customer feedback and building inside-in open innovation processes.

The research paper is laid out as follows: first, we provide the theoretical background and define the key concepts of the paper: dynamic capabilities, open innovation and competitive firm performance. Next, we describe the methodology and present the results. After discussing the results, we conclude with a discussion of the theoretical and practical implications, followed by the limitations of the paper and the suggested future work.

\section{Literature review and theoretical background}

\subsection{Dynamic capabilities}

Dynamic capabilities refer to "firms' ability to integrate, build, and reconfigure internal and external competencies to address rapidly changing environments" (Teece et al., 1997, p. 517). Dynamic capabilities encompass "the management of capabilities and resources of all functions of the firms, with the overall objective to get a competitive advantage" (Arranz et al., 2020, 
p. 1495). In reviewing the prior studies on dynamic capabilities, we noticed that scholars tend to measure diverse phenomena under the concept of dynamic capabilities, including R\&D, innovations, technology management, knowledge management, inter-organisational cooperation, decision-making, market research, alliances, networking, assets and reputation. For example, Karna et al. (2015) examined strategic human capital management, while Schilke (2014) investigated product development, alliance management and sense-making capabilities, and Li and Liu (2014) studied timely decision-making capabilities and change-making capabilities. Moreover, Drnevich and Kriauciunas (2011) examined the development of new products, services and business processes, as well as dynamic capability heterogeneity. Malik and Kotabe (2009) investigated organisational learning, reverse engineering and manufacturing flexibility, while Macher and Mowery (2009) examined dynamic capabilities through R\&D organisational practices (including intra-team diversity, inter-team diversity and co-location), along with information technology (IT) management practices.

As mentioned earlier, our paper is grounded in the dynamic capabilities and open innovation theories (Bogers et al., 2019; Chesbrough, 2003a; Teece, 2007, 2020; Teece et al., 2020). More explicitly, Teece (2012) defined dynamic capabilities as a set of capabilities comprised of sensing, seizing and transforming. However, Teece et al. (2020) in their most recent contribution split seizing into two separate groups of capabilities - orchestrating and value capture - that resulted in four groups of dynamic capabilities: sensing, orchestrating, value capture and transforming. Given the aims of the present paper, we deployed the latest version of dynamic capabilities grouping provided by Teece. Next, we discuss each cluster of dynamic capabilities in more detail to arrive at a taxonomy of dynamic capabilities that could serve as a measurement scale to test the proposed hypotheses and conceptual model.

\subsection{Taxonomy of dynamic capabilities}

There is legitimate concern as to whether a firm's dynamic capabilities can be identified, described and measured with a high degree of accuracy. So far, only a few papers have discussed and attempted to operationalise dynamic capabilities and proposed a more standardised measurement scale. In the present study, we relied on classical works, such as Teece (2007, 2020), Teece et al. (2020), Eisenhardt and Martin (2000), Helfat and Peteraf (2009, 2015), and Janssen et al. (2012), to distil the most commonly acknowledged and measurable constitution of dynamic capabilities clusters.

In this paper, we utilise the most recent version of dynamic capabilities classification provided by Teece et al. (2020), as it allows operationalising and consequently measuring firms' dynamic capabilities in a more systematic way. In this classification, as mentioned earlier, Teece suggested splitting the seizing capabilities into orchestrating and value capture capabilities to better reflect the two distinct processes and cognitive capabilities. Orchestrating capabilities involve integrating and reconfiguring relevant assets and motivating employees to engage in innovation processes; while value capture capabilities deal with business model innovation and gaining pecuniary and non-pecuniary benefits from innovation, in other words, commercialising the innovation. Following the approach taken by Teece et al. (2020) and based on a thorough analysis of recent studies, we propose a more precise classification of sensing capabilities into environment scanning and opportunity selection capabilities. These two capabilities rest on distinct actions and the cognitive capabilities of firms; whereby the former relates to relevant data detection and acquisition capabilities and the latter relates to data processing and sensemaking capabilities. Table 1 provides a more comprehensive overview of the calcifications of the dynamic capabilities.

\subsection{Open innovation}

Henry Chesbrough (2003a, p. 37) first defined open innovation "as a paradigm that assumes firms can and should use external and internal ideas as well as paths to market, if they aim to capabilities and
competitive firm
performance

155 
Second-order dynamic capabilities

Sensing

\section{6}

First-order dynamic

capabilities Description References

Environment scanning

Environment scanning might be defined as detecting, systemically collecting, combining, analysing and sharing data from diverse sources in order to monitor firms external and internal environment Opportunity selection

Opportunity selection is the identification, development and calibration of opportunities alongside external and internal customer needs and strategic challenges. Managers at various levels must generate and test hypotheses about latent consumer demand, technological possibilities and other forces that can affect the firm's future

$\begin{array}{ll}\text { Organising/ } & \begin{array}{l}\text { Employee } \\ \text { Orchestrating }\end{array} \\ \text { engagement }\end{array}$

Value capture

Commercialisation of innovations

Organisational

Transformation/ renewal
The asset orchestration capability is likely to depend on managers' cognitive capabilities for language and communication, as well as their social cognitive capabilities. Top management has a critical role to play to foster commitment [of employees] and to achieve engagement to innovation. Customer care is often relegated to employees; thus employees can have a significant impact on the performance of the firm

Value capture capabilities involve investing to commercialise new technologies as well as designing and implementing business model innovations for various products and services. Management must define clear priorities and objectives, along with appropriate metrics to benchmark progress A function of management is to find new value-enhancing combinations inside the enterprise, and between and among enterprises. Organisational learning and unlearning and the integration of knowledge support transformation of the organisation
Teece (2020, p. 3),

Teece et al. (2020,

p. 11), Helfat and

Peteraf (2015)

Teece (2020, p. 11), Helfat and Peteraf (2015)

Teece (2007), Helfat and Peteraf (2015, p. 842 )

Teece (2007, 2018, p. 364, 2020), Teece et al. (2020)

Teece (2007, p. 1341 , 2020)
Table 1.

Operationalisation of the dynamic capabilities advance their technology". Later, Chesbrough and Bogers (2014) extended the definition of open innovation to a distributed innovation process incorporating managed knowledge flows across organisational boundaries, using different mechanisms in line with the firm's business model. Moreover, open innovation allows a firm to combine both internal and external knowledge into its organisational architecture and systems, the requirements of which will be 
defined by its business model. According to Del Vecchio et al. (2018, p. 7), in the open innovation paradigm, firms share external and internal ideas and knowledge from outside as well as in-house and strive to make the boundary between the firm and their surrounding environment more porous and more co-operative. In the literature, scholars describe three kinds of open innovation strategies: outside-in (also known as inbound), inside-out (also known as outbound) (see Chesbrough and Bogers, 2014) and coupled (Enkel et al., 2009; Gassmann and Enkel, 2003).

An outside-in open innovation strategy is defined as a strategy to enhance a firm's owned knowledge base with relevant knowledge acquired from outside. Chesbrough and Bogers (2014) argued that knowledge generation, due to technological turbulence and market dynamism, has become extremely difficult for firms. Therefore, Ardito et al. (2018, p. 322) suggested, firms, through adopting an inbound (outside-in) open innovation strategy, look for an inflow of knowledge originating beyond their boundaries (i.e. external knowledge sourcing). Moreover, Elia et al. (2020) argued that firms, through outside-in activity, can absorb and internally use external knowledge "to exploit the discoveries of new ideas and leverage the relationships with external stakeholders to access and exploit their technical and market knowledge" (p. 2). As for the inside-out innovation strategy, Elia et al. (2020) related this to firms seeking to profit from letting external relevant actors exploit the internal knowledge of the firm; thereby complementing the internal development activities (p. 2).

The third type of open innovation, namely the "coupled open innovation strategy", involves a two-way exchange of knowledge mixing of outside-in and inside-out strategies through continuous interaction. Although, the process of open innovation, including knowledge management, has increasingly become distributed across organisational boundaries, the purpose of open innovation has remained the same: accelerating internal innovation and reinforcing the competitiveness of the firm. Garavelli et al. (2013, p. 25) argued that the emergence of the open innovation paradigm has promoted the proliferation of several strategies through which firms can exchange knowledge assets with their external environment. Since then, an extensive amount of research has been carried out to advance knowledge on the firm-centric aspects of open innovation, mainly dealing with knowledge, technology and R\&D management (e.g. Natalicchio et al., 2017; Randhawa et al., 2016). However, some areas remain under-researched. For example, studies deploying a resourcebased view or dynamic capabilities framework to explicate open innovation outcomes and success (Bogers et al., 2019; Lichtenthaler and Lichtenthaler, 2009; Natalicchio et al., 2018).

\subsection{The nexus between dynamic capabilities and competitive firm performance}

There have been a few empirical papers over the past decade that have empirically examined the relationship between dynamic capabilities, open innovation and competitive (advantage) firm performance. However, only a limited number of studies have explicitly investigated the relationships among all three concepts (e.g. Cheng and Chen, 2013). At the conceptual level, there are even fewer papers that discuss this topic in more detail (Augier and Teece, 2009; Helfat and Peteraf, 2009; Teece, 2007, 2014; Wang and Ahmed, 2007). This gap in the literature becomes even more apparent when compared with the more than 350 general papers published on dynamic capabilities annually (Albort-Morant et al., 2018).

Analysis of the literature reveals that there are three major areas of research in this area. Some scholars (Helfat and Peteraf, 2009; Protogerou et al., 2012; Zott, 2003) have examined the relationship between dynamic capabilities and competitive advantage or performance, either directly or indirectly. Other scholars (Drnevich and Kriauciunas, 2011; Karna et al., 2015; Protogerou et al., 2012) have compared ordinary and dynamic capabilities, analysing their impact on competitive advantage and performance. Finally, some scholars (e.g. Drnevich and Kriauciunas, 2011; Jantunen et al., 2005; Karna et al., 2015; Li and Liu, 2014; Schilke, 2014)
Dynamic
capabilities and
competitive firm
performance

157 
EJIM

25,6

158

have assessed the impact of environmental dynamics on the relationship between dynamic capabilities and firm competitive performance.

Schilke (2014) operationalised dynamic capabilities as alliance management and the new product development capabilities, while Protogerou et al. (2012) operationalised dynamic capabilities as coordination, learning and strategic competitive response capabilities as well as firm competitive advantage or, as in our case, competitive firm performance. Moreover, Schilke (2014) operationalised firm performance in terms of strategic performance and financial performance (i.e. earnings before interest and taxes (EBIT), return on investment (ROI) and return on sales (ROS)). Protogerou et al. (2012) operationalised performance as profitability and market performance, and Drnevich and Kriauciunas (2011) operationalised it as the relative process-level (use of IT) and firm-level (profitability) performance. Next to the operationalisation issue, Drnevich and Kriauciunas (2011) demonstrated the ambidextrous nature of dynamic capabilities, which can be leveraged between enhancing (incremental innovations) and developing new products, services and business processes (radical innovations) capabilities to assure superior performance. In this regard, some authors relate dynamic capabilities with innovation (Farzaneh et al., 2020). For instance, Karna et al. (2015) stated that dynamic capabilities stimulate innovation-related capabilities; however, the authors concluded that the prime nature of dynamic capabilities is to assure the efficient adaptation of the firm to volatile, uncertain, complex and ambiguous environments. Moreover, Hii and Neely (2000, p. 5) defined innovation capabilities as the "potential to generate new ideas, identify new market opportunities and implement marketable innovations by leveraging the existing resources and capabilities". As Lawson and Samson (2001) put forward innovation capabilities account for the transformation of knowledge and ideas into new processes, designs, services and products in order to increase the rents of the firm and its stakeholders. Furthermore, innovation capability is perceived as the ability to create and recombine knowledge to produce innovations, such as new services, processes, products and systems (Kogut and Zander, 1992).

While it can be seen from the literature that the majority of prior studies tended to assume an indirect relationship between dynamic capabilities and competitive firm performance, the question remains as to what mediates the impact of dynamic capabilities on competitive firm performance. As open innovation can be seen as purposively managing knowledge inflows and outflows in order to meet the needs of the firm for achieving a good firm competitive performance, we propose that open innovation mediates the path between dynamic capabilities and competitive firm performance.

\subsection{Open innovation as a mediator between dynamic capabilities and competitive firm performance}

Teece (2007) noted that dynamic capabilities empower the open innovation process with the ability to reach beyond internal and external organisational boundaries to access different resource types and to orchestrate them to fit the open innovation process through sensing, seizing (orchestrating and value capture capabilities) and transforming (Teece et al., 2020). Grimaldi et al. (2013) investigated whether firms with strong dynamic capabilities develop more open innovation processes than firms with weak dynamic capabilities. Based on a multiple-case study, Grimaldi et al. (2013) concluded that dynamic capabilities should support open innovation strategies for the firm to be competitive under the pressure of the current business environment. Furthermore, the authors indicated that firms need to be able to sense new partnership opportunities and sources of external knowledge, better seize commercialisation opportunities and finally transform internal and external resources to support open innovation and firm competitiveness. Later, Teece et al. (2016, p. 22) indicated that the seizing (orchestrating and value capture) capabilities, which are responsible for implementation and getting things done, might be augmented by adopting open innovation 
processes. Open innovation processes - outside-in and inside-out - support internal efforts to handle innovation effectively. For example, depending on the need, a firm might spin-off, spin-out or out-license technology to further develop it outside the incumbent firm (inside-out open innovation strategy). On the other hand, when a firm falls short in specific knowledge, it might in-license relevant intellectual property to effectually navigate innovation towards the expected commercial outcomes (outside-in open innovation strategy).

Bogers et al. (2019) matched dynamic capabilities (sensing, seizing and transforming) with open innovation strategies (outside-in and inside-out). They stated that sensing dynamic capabilities underpin the outside-in open innovation strategy through scanning, identifying, sense-making and selecting valuable external knowledge and technology. In addition, through their sensing capabilities, firms may detect and establish inter-organisational collaboration with relevant stakeholders, such as research institutions, start-ups and other technology firms. A less discussed external source of knowledge for which the sensing capabilities of the firm's open innovation processes might benefit are customers. Integrating customers' feedback as early as possible into the innovation process helps firm to save time and to achieve a better fit to the market. In our research, therefore, we not only regard customer engagement as one of the variables of open innovation, but also consider the position of customers as an essential external source of information. In conclusion, a firm's sensing capabilities are crucial under the current business environment for it to be able to detect the vast amount of diverse knowledge and technology that exists, to assess these against the firm's business needs, and to select the ones with the most potential to fit their needs while leaving aside the not relevant ones.

Seizing capabilities, on the other hand, are about executing identified and selected potential open innovation ideas well. Open innovation is not about outsourcing the research and development (R\&D) to third parties (Bogers et al., 2019, p. 84), rather, it is more about enhancing the internal innovation capabilities and contributing to the current business model or exploring a new business model. Thus, through seizing dynamic capabilities, firms invest in internal R\&D practices while leveraging outside-in and inside-out open innovation strategies. We also regard both pecuniary and non-pecuniary investments in the internal $R \& D$ projects as another significant variable of open innovation. These are also related with the firm's tolerance of risk while executing internal $R \& D$ projects. There are a number of risks related with open innovation initiatives, for example. collaborators can leak some trade secrets, the orchestration of multiple cooperating parties might fail, and there can be challenges related with complexity and openness.

Finally, open innovation is underpinned by transformation dynamic capabilities that are responsible for realigning the firm's organisation (structure) and culture in order to support inter- and intra-organisational cooperation and effectual knowledge management. Transformation capabilities are in particular useful when a new business line is introduced that requires a major revision of the current business model followed by critical changes in the organisational design. This is especially true with large incumbent firms that have one or more legacy business lines strongly protecting their identity, and effectively hindering intra-organisational cooperation and internal flows of knowledge. To reflect this under-researched phenomenon, we introduce a third component of open innovation: inside-in processes. Inside-in open innovation is responsible for internal collaboration among a firm's units and thus involves assuring a better flow of internally created knowledge and transformation of the organisation to better integrate external knowledge. Teece (2020, p. 15) in his recent work stated that "strong dynamic capabilities enable effective open innovation practices" and in turn assure the competitive performance of the firm. He also noted that firms with weak dynamic capabilities might fail to choose the right open innovation strategy, which might in turn be unsuccessfully governed and executed, leading to poor commercialisation and a poor performance of the firm.

\section{Dynamic capabilities and competitive firm performance}


EJIM

25,6

160

\section{Conceptual model and hypothesis development}

Grounded in the dynamic capabilities and open innovation theories (Chesbrough, 2003a; Teece, 2007, 2020; Teece et al., 2020), this research aimed to investigate the relationship between firms' dynamic capabilities, open innovation and firm competitive performance. Figure 1 depicts the path relationships in the proposed research model. We propose there is a direct relationship between dynamic capabilities and open innovation as well as a direct relationship between open innovation and competitive firm performance. Moreover, we assume the relationship between dynamic capabilities and competitive firm performance is mediated through open innovation. In the following subsections, detailed descriptions of each construct are provided.

\subsection{Dynamic capabilities}

Given that the strategic management literature has indicated that dynamic capabilities are measurable (Mikalef and Pateli, 2017, p. 1), and based on definitions provided in Table 1 as well as in the theoretical discussion given earlier, we operationalised dynamic capabilities as a function of five sub-dimensions: environment scanning, opportunity selection, employee engagement, commercialisation of innovations and organisational learning (Janssen et al., 2012). In other words, we could appropriately conceptualise this construct as a second-order latent construct. This assumption is further supported by Rindskopf and Rose (1988, p. 56), who indicated that a second-order factor structure puts a structure on the pattern of correlations among first-order factors. In this paper, both dynamic capabilities and open innovation, with their five and three sub-dimensions, satisfy this criterion and so we could expect to see a high correlation among all the first-order factors. In such a situation, secondorder factor models are preferred, not only because they are less complex (Chen et al., 2005), but also because, with this method, we can assess the causality among the first-order latent variables. Hence, we hypothesise that:

H1. Dynamic capabilities have a direct effect on open innovation.

\subsection{Open innovation}

For measurement purposes, we followed the structure of open innovation as proposed by Chesbrough (2012) (i.e. inside-out and outside-in). Inside-out innovation happens when unused

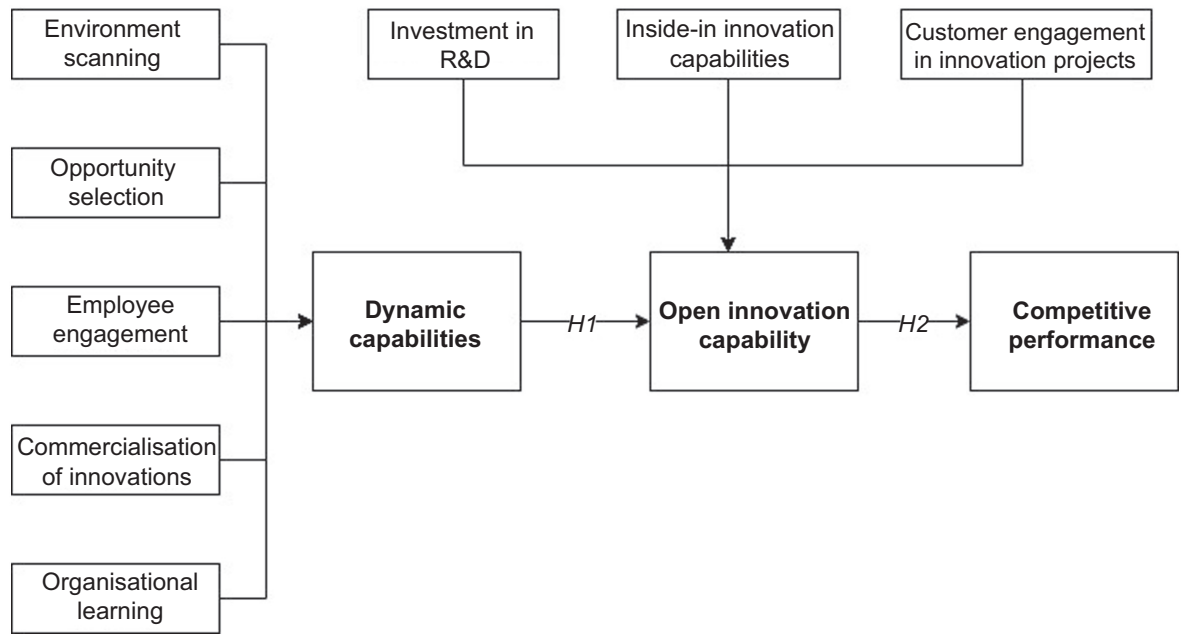

Figure 1.

Conceptual model 
or underutilised ideas are made available to external bodies by the firm, via investment in R\&D projects. Outside-in innovation refers to opening the organisational boundaries for different external inputs and contributions, especially those provided by customers (customer engagement in innovation projects). Chesbrough (2017, p. 37) noted that one of the current challenges of open innovation is managing its impact on internal innovation processes and successfully transferring inflowing new ideas and knowledge into and across the internal business units. He further stated that "it is striking how few open innovation success stories even discuss the transfer of the result into a downstream business unit. Therefore, more attention needs to be paid to the question of how to link the frontend of open innovation to the backend businesses that must take these inputs to the market". Furthermore, to fill the gap related to the internal focus of open innovation, we suggest a new component of open innovation and denote it as inside-in open innovation. This was partly mentioned in Gutmann (2019) in a different context, and it was also discussed during open innovation seminars hosted by Chesbrough et al. (2020). The inside-in innovation process is defined in more detail below. Building on the theoretical discussion provided above, we propose open innovation, as a function of three first-order reflective factors: (1) inside-out (investment in R\&D), (2) outside-in (customer engagement in innovation) and (3) inside-in innovation capabilities, should be considered as a second-order construct.

3.2.1 Open innovation: inside-out innovation processes. In the earliest phase of a nascent industry, users and hobbyists can do a lot by modifying the technologies already available to them. However, once the industry reaches some sort of dominant design, and where it begins to get to scale, significant capital investment is required to stay in the game (Chesbrough, 2012 , p. 26). Investments in R\&D projects allow innovation projects to create new knowledge and technology, capture value through intellectual property ownership and protection, and converge multiple technologies, as well as assuring the growth and scaling of the project outputs over time (Gnyawali and Park, 2011; Wang, 2015). Investments in R\&D projects contribute to inside-out innovation not only through scaling of the newly created knowledge and technologies, but also when unused or underutilised new knowledge and technology are made accessible through different mechanisms to third parties.

3.2.2 Open innovation: outside-in innovation processes. Customer engagement in innovation projects is perceived as a significant part of the outside-in open innovation process (Chesbrough, 2003a, b, c). Chesbrough (2003b) stated that if a firm overestimates an internal innovation process and neglects the external environment, such as customers, suppliers or business partners, it might lose competitive opportunities and its performance might lag when it comes to acquiring relevant information, intellectual property and other valuable resources. Wang et al. (2015a, b) found that especially in the high-technology industries collaboration with customers to acquire robust market-related information and to internalise it into the firm's innovation processes significantly contributes to competitive firm performance.

3.2.3 Open innovation: inside-in innovation processes. Inside-in processes are usually underestimated most of the time. In general, the inside-in concept means that the inclusiveness of different stakeholders in open innovation processes should also cover the efficient interaction of internal units and functions within the firm. Efficient collaboration among different internal units and functions assures the timely flow and sharing of needed competence and information, as well as ensuring the efficient coordination of management and frontline employee efforts towards the intended outcomes of the open innovation. To our understanding, orchestrated efforts across internal organisational boundaries to pursue superior open innovation outputs might be perceived as an inside-in open innovation process. Hence, we hypothesise that:

H2. Open innovation has a direct effect on competitive firm performance.

\section{Dynamic capabilities and competitive firm performance}


EJIM

25,6

162

\subsection{Competitive firm performance}

Competitive firm performance is a variable used in many studies that seek to assess firm success over time and within particular markets. For example, Richard et al. (2009) evaluated a firm's competitive actions and its relationship to particular business environments. The higher the level of uncertainty in the environment, the more critical were the non-financial indicators of competitive firm performance. In that situation, the critical success factors of firms include their strategies for new product development, innovation and investments in R\&D projects (Chenhall and Langfield-Smith, 2007; Gupta et al., 1987). One of the nonfinancial measures that primarily reflects a firm's performance compared to its competitors is firm competitive performance (Mikalef and Pateli, 2017), or relational performance (e.g. Drnevich and Kriauciunas, 2011). The most suitable evaluation of competitive firm performance is in comparison with both direct rivals and the overall industry (Mikalef and Pateli, 2017; Rothaermel, 2008).

\section{Research methodology}

To assess and measure dynamic capabilities, we followed the concept of micro-foundations as proposed by Teece $(2007,2018,2020)$, and Teece et al. (2020). Teece identified the lower-level and higher-level dynamic capabilities at the firm level and noted that unique managerial decisions, entrepreneurial activities and processes can be recognised as higher-level microfoundations of dynamic capabilities (Teece, 2007, 2018, 2020; Teece et al., 2020). For instance, through detecting new opportunities, selecting and pursuing those new opportunities, quickly responding to the relevant opportunities, orchestrating capabilities allow for continuous organisational transformation and learning. Teece $(2007,2018,2020)$ also identified the processes and routines of firms that can be recognised as lower-level microfoundations of dynamic capabilities, such as forming external partnerships, quality control, new product and service development and knowledge and technology transfer routines/ processes. We build on the definition of higher-level micro-foundations in the present study to measure the dynamic capabilities.

A similar issue arises regarding the measurement of open innovation and competitive firm performance. The most common framework for operationalising open innovation involves drawing on the firm-centric aspects, such as knowledge flows, technology transfer, investment in R\&D projects and intellectual property management. However, some scholars have noted that there is still insufficient understanding of the role of the user as an external source of innovation or of collaboration and co-creation within the internal boundaries of the organisation (Randhawa et al., 2016). As per competitive advantage, which in turn is measured as competitive firm performance (the performance of a firm compared with its competitors), Drnevich and Kriauciunas (2011) argued that perceptive or non-perceptive financial indicators, which are also rather heterogeneous across studies, can be used. While a handful of studies have used non-perceptive financial data to test the impact of dynamic capabilities on competitive firm performance (e.g. Schilke, 2014), most studies have tended to use perceptive data on financial or non-financial performance based on Likert or semantic differentiation scales (e.g. Wu, 2007). In the following, we discuss the measurement model, the items used to measure the constructs and our data-collection strategy.

\subsection{Developing a measurement model}

We conducted a literature review to select the most appropriate items to ensure the reliability of our measurement model. Therefore, all the items used in this paper were obtained from previously validated survey items. When needed, we made some minor modifications in the wording of the items to fit the context of the study. Dynamic capabilities, a second-order factor construct, were measured through five reflective first-order factors. The items were 
derived from Teece (2007, 2018, 2020; Teece et al., 2020), and Helfat and Peteraf (2015). We measured environmental scanning by using six items, opportunity selection with three items, and employee engagement, the commercialisation of innovations and organisational learning with five, three and three items, respectively. Open innovation items were adapted based on the studies by Chesbrough (2003 a, b, c) and Wang et al. (2015a, b). Inside-in was measured with five items, while inside-out and outside-in were measured with three and two items, respectively. Finally, four items for competitive firm performance (the dependent variable in the model) were adapted from Mikalef and Pateli (2017), see Table 2. To examine the path relationships in the model, we used structural equation modelling (SEM), which is a multivariate statistical technique that enables researchers to assess structural relationships and to examine how the constructs are related to other constructs in the model. We analysed the data using SmartPLS v.3 software (Ringle et al., 2015), based on partial least squares structural equation modelling (PLS-SEM), which focuses on improving the explained variance (Hair et al., 2017) and which differs from covariance-based SEM, in which the focus is on reproducing the theoretical covariance matrix.

\subsection{Survey administration, sample and data collection}

We developed a survey and contacted by telephone and email 6,177 Lithuanian technologyfocused firms operating in selected innovative and non-innovative economic sectors. To select the economic sectors, we used three criteria: (1) BERD (business enterprise R\&D expenditure), (2) percentage of new products, services and processes developed per year and (3) revenue from exports in relation to total revenue. Two non-innovative economic sectors (wood and wood fabric from thatch; and food) and five innovative economic sectors (information and communications; computer electronic and optical products; pharmaceutics; electricity, gas, ventilation and air-conditioning systems and finance and insurance) were selected.

This empirical research comprised three stages. The first stage was devoted to pilot testing the survey questionnaire. In the second stage, we collected 465 valid questionnaires to use in the analysis. This represented a response rate of 7.5\% (465 out of 6,177 telephone and email contacts). During the third stage, after the primary data was collected, secondary financial data, provided by Statistics Lithuania, were acquired for each of the firms that participated in the survey. The availability of the official financial data of the firms created an opportunity to use non-perceptive meanings of firm financial indicators to minimise the level of subjectivity. After the official financial data of the firms were attained, the names of the firms were deleted to assure confidentiality.

\section{Data analysis and results}

All the survey items were examined through several tests: reliability assessment, convergent validity and discriminant validity. In the following text, we report the results at the measurement model level. Out of the 465 firms, $48 \%$ of the managers had less than seven years' managerial experience, while the rest had more than seven years' experience. Furthermore, $189(40.6 \%)$ firms were from innovative sectors and indicated that they were actively trying to innovate, while $276(59.4 \%)$ firms were from non-innovative sectors and did not consider their firm to be innovation focused. Furthermore, we ran $t$-tests between the innovative sectors and non-innovative sectors, and the results showed that these two sectors were significantly different $(t=26.031$; $\mathrm{df}=464 ; p=0.001)$.

\subsection{Validity and reliability}

The internal consistency and the scale reliability of the constructs were examined through the composite reliability (CR), in which the threshold value of the $\mathrm{CR}$ is recommended to be capabilities and competitive firm performance 


\section{EJIM \\ 25,6}

Second-order construct
Dynamic capabilities;
Teece (2007, 2018, 2020), Teece
et al. (2020), Helfat and Peteraf
(2015)

First-order construct

Environment scanning

Opportunity selection

Employee engagement

Commercialisation of innovations

Organisational learning
Table 2.

Question items used in the study
Items

Your enterprise

ESCAN1: On a regular basis, assesses local and international market trends ESCAN2: On a regular basis, follows technology development trends ESCAN3: On a regular basis, appraises competitors and their products/services ESCAN4: On a regular basis, assesses customers' experiences and emerging needs

ESCAN5: Spares enough time for observing and evaluating the business environment

ESCAN6: Takes early notice of forthcoming environmental changes Your enterprise

OSELE1: Orients to high finance value projects even if they are risky

OSELE2: Takes bold strokes when looking for new opportunities OSELE3: Is looking for new and original ideas

Employees

EENGAG1: On a regular basis, submit innovative product/service ideas EENGAG2: Are encouraged to take calculated risks while implementing innovative ideas

EENGAG3: Invest their own time to work on innovation projects or services EENGAG4: Mostly are initiators of innovation projects

EENGAG5: Take part in the commercialisation of innovative products/services

CINNO1: Are happy about the success and return of innovative products/ services

CINNO2: Are capable of scaling up and commercialising our successful innovative products/services in local markets

CINNO3: Are always looking for innovative means around a barrier constraining consumption OLE1: Perceive failure of the project as an opportunity for learning and improvement

OLE2: Know that there is a database (or other tools) for storing needed information and experience OLE3: Consider permanent learning (in various forms) an important component of their work activities

(continued) 


\section{Second-order construct}

Open innovation;

Chesbrough (2003 a, b, c)

and Wang et al. (2015a, b)

Competitive firm performance; Mikalef and Pateli (2017)

First-order construct
Open innovation: inside-out
(investments in R\&D projects)

Open innovation: outside-in (customer engagement in innovation projects)

Open innovation: inside-in (efficient collaboration of internal units)
Items

INVEST1: Your enterprise dedicates resources and funds to support innovation projects

INVEST2: Your enterprise invests in research and development (R\&D) INVEST3: Your enterprise funds experimental projects realising that some of them will undoubtedly fail CENGA1: At an early stage, innovative ideas are tested with customers CENGA2: If an innovative idea does not pass the customer test, the project is cancelled

INSIDE1: Employees are proficient in project management

INSIDE2: Coordination and communication among business units and project teams are timely and efficient

INSIDE3: Existing processes and decision-making tools support each stage of innovation development INSIDE4: It is clearly set when to proceed with innovative product/ service development, when to cut it, increase/decrease investment, etc. INSIDE5: Existing innovation project management tools support to achieve satisfactory innovation speed, return of investment and outcomes

FPER1: Sales of our enterprise rise more than $20 \%$ per year

FPER2: Sales of our enterprise rise faster than sales of our competitors FPER3: Our enterprise creates more products/services per year than our competitors

FPER4: Our enterprise's new products/ services receive better evaluations than the new products/services of our competitors

\section{capabilities and competitive firm performance}

Dynamic

0.70 or higher (Hair et al., 2011). In our assessment of construct reliability, as can be seen in Table 3 , the lowest $\mathrm{CR}$ value was 0.84 . This indicates that all the constructs satisfied the threshold value; therefore, we established the acceptable construct reliability. Furthermore, the internal consistency was assessed via Cronbach's alpha, which is a measure of the internal reliability of latent constructs, in which the threshold value is recommended to be 0.70 (Hair et al., 2012). Our results showed that all but one construct (customer engagement in innovation project $=0.65$ ) satisfied the threshold, suggesting an acceptable construct reliability.

We also examined the convergent validity, which refers to the degree by which two measures of constructs that theoretically should be related are in fact related. According to Hair et al. (2011), the relationship can be examined by the average variance extracted (AVE), 
EJIM

25,6

\begin{tabular}{lccc}
\hline & $\begin{array}{c}\text { Cronbach's } \\
\text { alpha }\end{array}$ & $\begin{array}{c}\text { Composite } \\
\text { reliability }\end{array}$ & $\begin{array}{c}\text { Average variance extracted } \\
\text { (AVE) }\end{array}$ \\
\hline Competitive firm performance & 0.80 & 0.87 & 0.62 \\
Environment scanning & 0.81 & 0.86 & 0.56 \\
Opportunity selection & 0.79 & 0.87 & 0.71 \\
Employee engagement & 0.85 & 0.89 & 0.63 \\
Commercialisation of innovations & 0.71 & 0.84 & 0.63 \\
Organisational learning & 0.76 & 0.86 & 0.67 \\
Investment in R\&D & 0.80 & 0.88 & 0.72 \\
Customer engagement in & 0.65 & 0.81 & 0.68 \\
innovation & & 0.89 & 0.62 \\
Inside-in innovation capabilities & 0.85 & &
\end{tabular}

Table 3.

Descriptive statistics

\begin{tabular}{|c|c|c|c|c|c|}
\hline & Construct & Item & Loadings & Mean & Std. dev \\
\hline \multirow[t]{20}{*}{ Dynamic capabilities } & \multirow[t]{6}{*}{ Environment scanning } & ESCAN_1 & 0.77 & 7.81 & 2.31 \\
\hline & & ESCAN_2 & 0.79 & 7.96 & 3.07 \\
\hline & & ESCAN_3 & 0.72 & 6.01 & 3.1 \\
\hline & & ESCAN_4 & 0.70 & 7.95 & 2.76 \\
\hline & & ESCAN_5 & 0.76 & 6.52 & 2.76 \\
\hline & & ESCAN_6 & 0.76 & 7.78 & 2.48 \\
\hline & \multirow[t]{3}{*}{ Opportunity selection } & OSELE_1 & 0.76 & 5.96 & 3.09 \\
\hline & & OSELE_2 & 0.90 & 5.87 & 2.89 \\
\hline & & OSELE_3 & 0.86 & 7.09 & 2.75 \\
\hline & \multirow[t]{5}{*}{ Employee engagement } & EENGAGG_1 & 0.82 & 6.34 & 2.38 \\
\hline & & EENGAG_2 & 0.76 & 6.05 & 2.48 \\
\hline & & EENGAG_3 & 0.76 & 5.23 & 3.09 \\
\hline & & EENGAG_4 & 0.79 & 6.05 & 1.98 \\
\hline & & EENGAG_5 & 0.82 & 7.05 & 3.07 \\
\hline & \multirow[t]{3}{*}{ Commercialisation of innovations } & CINNO_1 & 0.81 & 7.23 & 1.99 \\
\hline & & CINNO_2 & 0.79 & 6.23 & 2.54 \\
\hline & & CINNO_3 & 0.79 & 7.39 & 5.11 \\
\hline & \multirow[t]{3}{*}{ Organisational learning } & OLE_1 & 0.80 & 6.49 & 2.68 \\
\hline & & OLE_2 & 0.81 & 7.33 & 3.19 \\
\hline & & OLE_3 & 0.86 & 6.89 & 3.26 \\
\hline \multirow[t]{10}{*}{ Open innovation } & \multirow[t]{5}{*}{ Open innovation: inside-in } & INSIDE_1 & 0.74 & 6.53 & 2.34 \\
\hline & & INSIDE_2 & 0.82 & 5.45 & 1.94 \\
\hline & & INSIDE_3 & 0.85 & 5.43 & 3.31 \\
\hline & & INSIDE_4 & 0.74 & 6.43 & 2.07 \\
\hline & & INSIDE_5 & 0.80 & 8.49 & 2.21 \\
\hline & \multirow[t]{3}{*}{ Open innovation: inside-out } & INVEST_1 & 0.82 & 4.32 & 1.27 \\
\hline & & INVEST_2 & 0.88 & 5.76 & 2.31 \\
\hline & & INVEST_3 & 0.83 & 3.57 & 3.07 \\
\hline & \multirow[t]{2}{*}{ Open innovation: outside-in } & CENGA_1 & 0.92 & 6.96 & 2.84 \\
\hline & & CENGA_2 & 0.73 & 7.70 & 2.93 \\
\hline \multirow{4}{*}{\multicolumn{2}{|c|}{ Competitive firm performance }} & FPER_1 & 0.70 & 6.01 & 3.02 \\
\hline & & FPER_2 & 0.85 & 7.95 & 3.05 \\
\hline & & FPER_3 & 0.79 & 4.52 & 2.43 \\
\hline & & FPER_4 & 0.81 & 6.08 & 2.87 \\
\hline
\end{tabular}

Table 4.

Descriptive statistics, factor loadings 
and the recommended threshold of AVE is 0.50 or higher (Fornell and Larcker, 1981). Here, all the AVE values were between 0.56 and 0.72 , and thus convergent validity was established in our data. Moreover, all the survey items exceeded the recommended threshold value for factor loadings, as they were all above 0.70 (see Table 4). All survey items were measured using 10-Point Likert Scale.

\subsection{Discriminant validity}

The discriminant validity test, unlike for convergent validity, aims to establish that there is no correlation or relation between the measurements or concepts. In other words, for the discriminant validity, the aim is to show that the measures that were supposed to measure a construct actually measured the intended construct and that the construct was not captured with other measures (Henseler et al., 2015). Based on the Fornell and Larcker (1981) criterion and the values provided in Table 5 , we were able to establish the distinctness of the constructs and the discriminant validity in our data.

Furthermore, we examined the multicollinearity issue. This assessment should be performed if the dependent variable (competitive firm performance) in the model is predicted by more than one independent variable. Because there might be a possibility of intercorrelation among the dependent variables, the multicollinearity was examined upon assessing the value of variance inflation factor (VIF). Several authors, such as Hair et al. (1998) and Petter et al. (2007), have recommended that the lowest acceptable VIF value is 3.3. Based on the values presented in Table 6, we established that multicollinearity was not an issue in our data.

To determine the bias, if any, attributed to the measurement method, we examined the common method bias (CMB). We tested the CMB through two different approaches: (1) Harman's one-factor test, as recommended by Podsakoff and Organ (1986), which revealed that none of the constructs had a value of more than $50 \%$ of the variance, and (2) the common

\begin{tabular}{|c|c|c|c|c|c|c|c|c|c|c|}
\hline & 1 & 2 & 3 & 4 & 5 & 6 & 7 & 8 & 9 & \\
\hline 1. Commercialisation of innovations & 0.79 & & & & & & & & & \\
\hline 2. Competitive firm performance & 0.52 & 0.79 & & & & & & & & \\
\hline 3. Customer engagement in innovation & 0.31 & 0.27 & 0.83 & & & & & & & \\
\hline 4. Employee engagement & 0.43 & 0.39 & 0.26 & 0.79 & & & & & & \\
\hline 5. Environment scanning & 0.52 & 0.45 & 0.38 & 0.48 & 0.75 & & & & & \\
\hline 6. Inside-in innovation capabilities & 0.57 & 0.38 & 0.33 & 0.53 & 0.56 & 0.79 & & & & Table 5. \\
\hline 7. Investment in R\&D & 0.42 & 0.39 & 0.33 & 0.48 & 0.44 & 0.48 & 0.84 & & & Correlation among \\
\hline 8. Opportunity selection & 0.45 & 0.49 & 0.33 & 0.42 & 0.54 & 0.44 & 0.44 & 0.84 & & constructs and the \\
\hline 9. Organisational learning & 0.49 & 0.41 & 0.30 & 0.45 & 0.53 & 0.55 & 0.42 & 0.46 & 0.82 & square root of the AVE \\
\hline
\end{tabular}

Dynamic capabilities and competitive firm performance

167

\begin{tabular}{lrr}
\hline Construct & VIF \\
\hline Employee engagement & 1.471 \\
Opportunity selection & 1.579 \\
Commercialisation of innovations & 1.581 \\
Organisational learning & 1.642 \\
Environment scanning & 1.846 \\
Customer engagement in innovation & 1.227 \\
Inside-in innovation capabilities & 1.964 \\
Investment in R\&D & 1.556 & Multicollinearity \\
& diagnostics \\
\hline
\end{tabular}


EJIM

25,6

168

latent factor (CLF) technique, as recommended by Podsakoff et al. (2003). MacKenzie and Podsakoff (2012) argued that the CLF provides a more robust understanding of the CMB than from Harman's one-factor test. Using the CLF approach, we compared the chi-square values of two models: unconstrained model versus a model where all the paths were constrained to zero. According to the results, no path in the model was affected by CMB.

\subsection{Structural model analysis}

Figure 2 shows the results of the structural model, including the explained variance $\left(R^{2}\right)$ of the firm competitive performance and open innovation. As we used PLS-SEM to perform the structural analysis, we cannot report on the model fit. However, we can report on the Standardised Root Mean Square Residual (SRMR). This measure is used in PLS studies to assess the model fit. It refers to the difference between the observed correlation and the model implied correlation matrix. Henseler et al. (2014) and Hu and Bentler (1998) argued that a value of less than 0.10 (or 0.080 in a more conservative version) could be considered a good fit. In our analysis, the SRMR value was 0.078 , which is consistent with the recommended value. To obtain the significance of the estimates ( $t$-statistics) in the path model, a bootstrap analysis with 5,000 resamples was computed. We also examined several alternative conceptualisations of our proposed model, and the results showed that the model presented in Figure 2 was the most appropriate and provided support for our hypotheses.

We ran chi-square difference tests for the conceptual model to make sure that using the second-order constructs model was, in fact, a viable approach. The results of the chi-square difference tests showed differences at both the measurement and the structural model levels, providing statistical support for the use of the second-order factor model. Competitive firm performance was explained by a variance of $32 \%$. Open innovation was explained by a $49 \%$ variance. Bagozzi et al. (1991) argued that when a second-order factor model is used, the value of the correlations among all the first-order factors must be lower than 0.90. Our results showed that the correlation values among all five first-order factors of dynamic capabilities and the three first-order factors of open innovation capability were below the threshold value of 0.90 .

Figure 2.

Conceptual model result

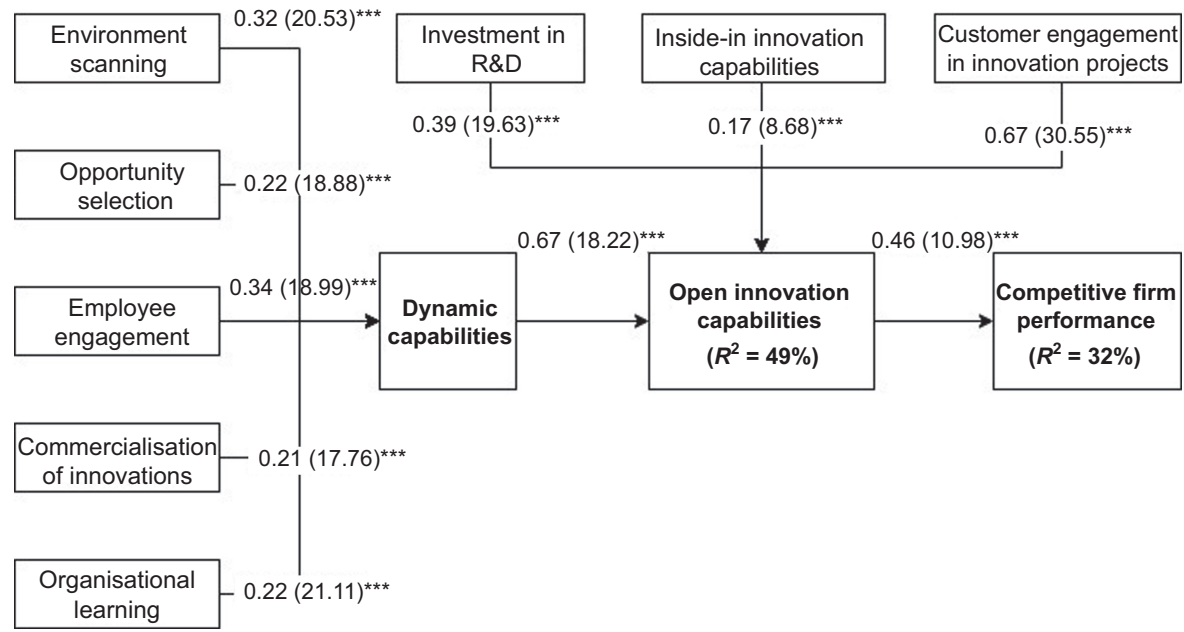

Note(s): ${ }^{* *} p$-value $<0.001 ;{ }^{* *} p$-value $<0.01 ;{ }^{*} p$-value $<0.05$ 
The SEM results showed that all five first-order factors of dynamic capabilities - environment scanning $(\beta=0.32, t=20.53, p<0.001)$, opportunity selection $(\beta=0.22, t=18.88, p<0.001)$, employment engagement $(\beta=0.34, t=18.99, p<0.001)$, commercialisation of innovation $(\beta=0.21, t=17.76, p<0.001)$ and organisational learning $(\beta=0.22, t=21.11, p<0.001)-$ all had a positive and significant impact on their respective constructs. Moreover, the SEM results revealed that all three first-order factors - inside-out innovation $(\beta=0.39, t=19.63, p<0.001)$, inside-in innovation $(\beta=0.17, t=8.68, p<0.001)$ and outside-in innovation $(\beta=0.67, t=30.55$, $p<0.001)$ - all contributed positively to open innovation, see Figure 2. According to our conceptualisation, we propose that there is a direct relationship between dynamic capabilities and open innovation. The SEM analysis revealed that dynamic capabilities positively influenced open innovation $(\beta=0.67, t=18.22, p<0.001)$; thus, $\mathrm{H} 1$ was supported by the model. Moreover, the SEM results showed that open innovation significantly influences competitive firm performance $(\beta=0.46, t=10.98, p<0.001)$; thus, $\mathrm{H} 2$ was supported by the model. Since the research model assumes that the impact of dynamic capabilities on competitive firm performance is mediated through open innovation, we performed a mediation test. The result showed that dynamic capabilities have a significant total indirect effect on firm competitive performance. Then, we checked the value of the specific indirect effects in the pathway between dynamic capabilities and competitive firm performance and found a positive relationship with a significant value $(\beta=0.35$, $t=9.439, p<0.001$ ). This result indicates that open innovation partially mediates the path between dynamic capabilities and competitive firm performance.

In the final step, we ran multigroup analysis (MGA) on the firms from the innovative and non-innovative sectors to examine what difference, if any, could be attributed to the sector in which the firms participated in. We divided the sample into two groups: innovative firms (Group 1) and non-innovative firms (Group 2). The result showed that the path relationship between dynamic capabilities and open innovation was significant for firms in noninnovative sectors $(\beta=0.005, t=2.277, p<0.05)$ and it was not significant for firms in innovative sectors. However, we should notice that the effect was weak, albeit the difference between the two groups in this path was established.

\section{Discussions and implications}

\subsection{Discussion}

We started the paper by showing that, although there is a vast amount of research on dynamic capabilities, open innovation and firm performance, still little is known about the role and constitution of open innovation in relation to dynamic capabilities and competitive firm performance. To close this gap, we assessed the impact of dynamic capabilities on firm competitive performance assuming that open innovation mediates this relationship. To measure open innovation, we relied on Chesbrough's (2003a, b, c, 2012) definition and his comments that, surprisingly, scholars pay too little attention to the internal organisational innovation processes. Consequently, we proposed a new component of open innovation and denoted it as inside-in, which complements the existing classification of open innovation processes with a targeted focus on purposefully managed flows of knowledge and resources across internal organisational boundaries. This third novel component of open innovation was proved to play a significant role in measuring open innovation as well as the role that it plays in the path between dynamic capabilities and firm competitive performance.

Schilke et al. (2018) argued that even though some relatively recent studies have provided inputs into the disciplinary foundations and other selected aspects of dynamic capabilities, they, however, have not provided a comprehensive framework to fully understand the antecedents, dimensions, mediating mechanisms and the effects of dynamic capabilities on competitive firm performance. In their paper, Schilke et al. (2018) concluded that dynamic capabilities do not have a direct impact on the "consequences" as the relationship is mediated by the "mechanisms" and/or moderated by organisational and/or environmental factors.

\section{Dynamic capabilities and competitive firm performance}


EJIM

25,6

Our study provides empirical evidence that one of the significant mechanisms mediating the relationship between dynamic capabilities and the performance of the technological firm is open innovation. Thus, we confirmed that the relationship between dynamic capabilities and competitive firm performance is partially mediated by open innovation. Dynamic capabilities through sensing, orchestrating, value capture and reconfiguring capacities (Teece, 2020), as second-order factors, drive open innovation and enrich the firm's innovation processes through two-way communication and the exchange of knowledge and other valuable resources across the external and internal boundaries of the firm. Thus, this paper empirically proved the conceptual consideration provided by Wilden et al. (2016), Bogers et al. (2019) and Teece et al. (2020), who stated that dynamic capabilities create value through integrating, combining and reconfiguring operational capabilities or micro-foundations (Teece et al., 2020) and thus have an indirect impact on firm performance mediated by the processes and routines that contribute to the deployment of the firm strategy. We theoretically contribute to the previous conceptual discussions that dynamic capabilities might be regarded as antecedents of open innovation, in the way that they can enhance the effectiveness and potential success of the open innovation. A firm with weak dynamic capabilities is less likely to successfully utilise open innovation processes.

Another contribution of this paper is the developed taxonomy of dynamic capabilities, where we discussed different issues surrounding dynamic capabilities and used the developed taxonomy to operationalise our measurement tool based on Teece's (2020) classification of dynamic capabilities. Based on the literature review and a statistical grinding of the dynamic capabilities scale, we elaborated the five first-order reflective factors of dynamic capabilities: environment scanning, opportunity selection, employee engagement, commercialisation of innovation and organisational learning. This led us to unfold several learning points. First, in contrast with prior research (Helfat and Peteraf, 2009, 2015; Teece, 2007) that emphasises the role of the top and middle management in building and maintaining dynamic capabilities, our results indicated and highlighted the role of employee engagement as a significant component of the dynamic capabilities of firms. Employees' proactive engagement - in devoting their own time to working on innovative projects, submitting innovative ideas, taking risks and staying involved in the commercialisation of the developed products and services - contributes to the firm's dynamic capabilities and, in turn, enhances its open innovation.

Second, our findings prove that "environment scanning" and "opportunity selection" are two distinct components of sensing capabilities. Although, Teece (2007, p. 1322) defined sensing capabilities as "scanning, creation, learning and interpretive activity", more in-depth theoretical and, later, empirical investigations have led to the notion that "environment scanning" -detecting, systemically collecting, combining, analysing and sharing data from diverse sources in order to monitor firms external and internal environment (Teece, 2020, p. 3; Tecce et al., 2020, p. 11) - and "opportunity selection"-identification, development and calibration of opportunities with external and internal customer needs and strategic challenges (Teece et al., 2020, p. 11) - are two separate constructs of sensing capabilities based on different organisational processes, routines and cognitive skills. This adds to a more accurate measurement of dynamic capabilities. Such an extended scale of dynamic capabilities might aid future research, but also have a more purposeful impact on the development of dynamic capabilities.

\subsection{Theoretical implications}

The results of the present study extend the open innovation theory by confirming that dynamic capabilities serve as an antecedent of open innovation in firms pursuing competitive firm performance. Furthermore, the study added a third component of open innovation; whereby, besides inside-out and outside-in open innovation, inside-in open innovation processes play a significant role in competitive firm performance. The inside-in open 
innovation component is related with the effectual exchange of knowledge and other valuable resources between the internal units of a firm. These processes, so far, have been neglected in the open innovation literature; thus we hope our paper opens this up as a new area for open innovation researchers.

The paper also contributes to the dynamic capabilities framework by explicating the missing link between dynamic capabilities and competitive firm performance. The research results confirm that the indirect impact of dynamic capabilities on competitive firm performance is mediated through open innovation. Furthermore, we found that dynamic capabilities have a significant impact on open innovation (explained by a variance of $49 \%$ ) and these two factors together have a significant impact on competitive firm performance (explained by a variance of $32 \%$ ).

\subsection{Managerial implications}

The results of the present study have some managerial implications too. For example, open innovation is an important factor in pursuing competitive firm performance and investment in $R \& D$ and innovation projects can help a firm to develop and exchange the knowledge needed for strengthening the competitive performance of the firm. However, based on our findings, it is also very important to assess the relevance of the developed knowledge with the customers, which can ensure that the value created by R\&D and innovation will be appropriated. In addition, to better understand the open innovation processes - inside-out and outside-in - managers should be mindful about the third component of open innovation: the inside-in processes. The study confirmed, that if the firm has less effectual internal innovation processes, its open innovation outcomes will be impeded. Thus, we suggest managers should split their attention equally between the external and internal innovation processes. The internal knowledge diffusion processes are often underestimated. Moreover, to empower open innovation, firms should strengthen their dynamic capabilities through constantly scanning the external and internal business environments, boldly selecting new opportunities, engaging employees, cultivating the capability to capture value, and constantly renewing their organisational design through multiple-loop organisation experiential learning. Dynamic capabilities in conjunction with open innovation can help firms to increase their competitive performance.

\section{Conclusions, limitations and future research}

The present study aimed to examine the effect of dynamic capabilities on open innovation and, in turn, the mediating role of open innovation in the relationship between dynamic capabilities and firm competitive performance. To pursue this aim, we operationalised dynamic capabilities as a second-order reflective-formative construct composed of five firstorder reflective factors, as recommended by Teece (2020) and Ringle et al. (2012) in the latest extension of his dynamic capabilities. Also based on a literature analysis, we propose a new component of open innovation - inside-in - which complements the outside-in and inside-out innovation processes.

Based on a survey of 465 technological firms, and using structural equation modelling, we tested two research hypotheses. The SEM results provided theoretical support for both hypotheses. We showed that open innovation as a mediator explains competitive firm performance by a variance of $32 \%$. That means that the stronger the dynamic capabilities of the firm, the stronger the open innovation is, as well as the more competitive the firm performance is. Furthermore, dynamic capabilities could explain open innovation with a variance of $49 \%$, thus, dynamic capabilities can be considered an antecedent of open innovation. Interestingly, the findings showed that employee engagement and inside-in innovation are highly correlated. Thus, this might indicate that (1) if employees are not actively involved in innovation projects and (2) if
Dynamic
capabilities and competitive firm performance 
EJIM

25,6

there is no closed loop in communication, and knowledge sharing and the sharing of other assets across internal organisational boundaries is limited, the firm will not be able to fully achieve a superior competitive performance.

Besides, the research findings prove that our proposed third component of open innovation, labelled as inside-in innovation, is a significant predictor of open innovation. Finally, by proposing and testing a conceptual model, this paper contributes to the open innovation and dynamic capabilities literature by showing that dynamic capabilities indirectly impact the competitive performance of technological firms through the mediating mechanism of open innovation.

The study has several limitations to note. First, the study was based on the data collected from one EU country - Lithuania, which is considered a moderate innovation economy (European Commission and European Innovation Scoreboard, 2020). Thus, economies that are identified as innovation leaders, strong innovators and modest innovators might be studied in the future. Second, based on the literature review, we believe we selected the most significant mediating factor, i.e. open innovation, and did not take into account other potential factors that might also facilitate the relationship between dynamic capabilities and competitive firm performance. So, other factors that might potentially facilitate the relationship between dynamic capabilities, open innovation and competitive firm performance still need to be explored. Another limitation of this paper might be the fact that we did not examine if open innovation moderates the pathway between dynamic capabilities and firm competitive performance. Finally, we tested sector innovativeness as a control variable; thus other possible control variables might be tested in future research.

Although our paper addresses a number of significant issues related to dynamic capabilities, open innovation and competitive firm performance, future studies are recommended to contribute to a further elaboration of the third component of open innovation: the inside-in innovation processes introduced in this paper. Furthermore, exploration of the interactions in inside-in open innovation with the specific constructs of dynamic capabilities is recommended. For example, future studies may try to understand what role inside-in innovation processes play in scanning, opportunity selection, employee engagement, the commercialisation of innovation and organisational learning. Last but not least, it would be interesting to compare the results of our study with the results of similar research carried out in innovation leader economies.

\section{References}

Albort-Morant, G., Leal-Rodríguez, A.L., Fernández-Rodríguez, V. and Ariza-Montes, A. (2018), "Assessing the origins, evolution and prospects of the literature on dynamic capabilities: a bibliometric analysis", European Research on Management and Business Economics, Vol. 24 No. 1, pp. 42-52.

Ardito, L., Petruzzelli, A.M., Dezi, L. and Castellano, S. (2018), "The influence of inbound open innovation on ambidexterity performance: does it pay to source knowledge from supply chain stakeholders?”, Journal of Business Research, Vol. 119, pp. 321-329.

Arranz, N., Arroyabe, M., Li, J. and Fernandez de Arroyabe, J.C. (2020), "Innovation as a driver of ecoinnovation in the firm: an approach from the dynamic capabilities theory", Business Strategy and the Environment, Vol. 29 No. 3, pp. 1494-1503.

Arthurs, J.D. and Busenitz, L.W. (2006), "Dynamic capabilities and venture performance: the effects of venture capitalists", Journal of Business Venturing, Vol. 21 No. 2, pp. 195-215.

Augier, M. and Teece, D.J. (2009), "Dynamic capabilities and the role of managers in business strategy and economic performance", Organization Science, Vol. 20 No. 1, pp. 410-421.

Bagozzi, R.P., Yi, Y. and Phillips, L.W. (1991), "Assessing construct validity in organisational research", Administrative Science Quarterly, Vol. 36 No. 3, pp. 421-458. 
Bitencourt, C.C., Santini, F.D., Ladeira, W., Santos, A.C. and Teixeira, E.K. (2020), "The extended dynamic capabilities model: a meta-analysis", European Management Journal, Vol. 38 No. 1, pp. 108-120, doi: 10.1016/j.emj.2019.04.007.

Bogers, M., Chesbrough, H., Heaton, S. and Teece, D.J. (2019), "Strategic management of open innovation: a dynamic capabilities perspective", California Management Review, Vol. 62 No. 1, pp. 77-94.

Chen, F.F., Sousa, K.H. and West, S.G. (2005), "Teacher's corner: testing measurement invariance of second-order factor models", Structural Equation Modelling, Vol. 12 No. 3, pp. 471-492.

Cheng, C.C.J. and Chen, J. (2013), "Breakthrough innovation: the roles of dynamic innovation capabilities and open innovation activities", Journal of Business and Industrial Marketing, Vol. 28 No. 5, pp. 444-454.

Chenhall, R.H. and Langfield-Smith, K. (2007), "Multiple perspectives of performance measures", European Management Journal, Vol. 25 No. 4, pp. 266-282.

Chesbrough, H. (2003a), "The logic of open innovation: managing intellectual property", California Management Review, Vol. 45 No. 3, pp. 33-58.

Chesbrough, H. (2003b), Open Innovation, Harvard University Press, Cambridge, MA.

Chesbrough, H. (2003c), Open Innovation: The New Imperative for Creating and Profiting from Technology, Harvard Business School Press, Boston, MA.

Chesbrough, H. (2012), "Open innovation: where we have been and where we're going”, ResearchTechnology Management, Vol. 55 No. 5, pp. 20-27, doi: 10.5437/08956308X5504085.

Chesbrough, H. (2017), "The future of open innovation: the future of open innovation is more extensive, more collaborative, and more engaged with a wider variety of participants", Research-Technology Management, Vol. 60 No. 1, pp. 35-38.

Chesbrough, H. and Bogers, M. (2014), "Explicating open innovation: clarifying an emerging paradigm for understanding innovation", Forthcoming, in Chesbrough, H., Vanhaverbeke, W. and West, J. (Eds), New Frontiers in Open Innovation, Oxford University Press, Oxford, pp. 3-28, available at: https://ssrn.com/abstract $=2427233$.

Chesbrough, H., Heaton, S. and Mei, L. (2020), "Open innovation with Chinese characteristics: a dynamic capabilities perspective”, R\&D Management, doi: 10.1111/radm.12438.

Del Vecchio, P., Di Minin, A., Petruzzelli, A.M., Panniello, U. and Pirri, S. (2018), "Big data for open innovation in SMEs and large corporations: trends, opportunities, and challenges", Creativity and Innovation Management, Vol. 27 No. 1, pp. 6-22.

Drnevich, P.L. and Kriauciunas, A.P. (2011), "Clarifying the conditions and limits of the contributions of ordinary and dynamic capabilities to relative firm performance", Strategic Management Journal, Vol. 32 No. 3, pp. 254-279.

Eisenhardt, K.M. and Martin, J.A. (2000), "Dynamic capabilities: what are they?", Strategic Management Journal, Vol. 21 No. 11, pp. 1105-1121.

Elia, G., Petruzzelli, A.M. and Urbinati, A. (2020), "Implementing open innovation through virtual brand communities: a case study analysis in the semiconductor industry", Technological Forecasting and Social Change, Vol. 155, doi: 10.1016/j.techfore.2020.119994.

Enkel, E., Gassmann, O. and Chesbrough, H. (2009), "Open R\&D and open innovation: exploring the phenomenon”, R\&D Management, Vol. 39 No. 4, pp. 311-316.

European Commission and European Innovation Scoreboard (2020), available at: https://ec.europa.eu/ commission/presscorner/detail/en/QANDA_20_1150 (accessed 5 April 2021).

Farzaneh, M., Ghasemzadeh, P., Nazari, J.A. and Mehralian, G. (2020), "Contributory role of dynamic capabilities in the relationship between organizational learning and innovation performance", European Journal of Innovation Management, pp. 1460-1060, doi: 10.1108/ EJIM-12-2019-0355, available at: https://www.emerald.com/insight/content/doi/10.1108/EJIM12-2019-0355/full/pdf?title=contributory-role-of-dynamic-capabilities-in-the-relationshipbetween-organizational-learning-and-innovation-performance. 
EJIM

25,6

Ferreira, J., Coelho, A. and Moutinho, L. (2020), "Dynamic capabilities, creativity and innovation capability and their impact on competitive advantage and firm performance: the moderating role of entrepreneurial orientation", Technovation, Vol. 92, p. 102061.

Fornell, C. and Larcker, D.F. (1981), "Evaluating structural equation models with unobservable variables and measurement error”, Journal of Marketing Research, Vol. 18 No. 1, pp. 39-50.

Fortunato, A., Gorgoglione, M., Messeni Petruzzelli, A. and Panniello, U. (2017), "Leveraging big data for sustaining open innovation: the case of social TV", Information Systems Management, Vol. 34 No. 3, pp. 238-249.

Garavelli, A.C., Petruzzelli, A.M., Natalicchio, A. and Vanhaverbeke, W. (2013), "Benefiting from markets for ideas - an investigation across different typologies", International Journal of Innovation Management, Vol. 17 No. 6, pp. 1-37.

Gassmann, O. and Enkel, E. (2003), "Towards a theory of open innovation: three core process archetypes”, R\&D Management Conference (RADMA) 2004. Lisbon.

Gnyawali, D.R. and Park, B.J. (2011), "Co-opetition between giants: collaboration with competitors for technological innovation”, Research Policy, Vol. 40 No. 5, pp. 650-663.

Grimaldi, M., Quinto, I. and Rippa, P. (2013), "Enabling open innovation in small and medium enterprises: a dynamic capabilities approach", Knowledge and Process Management, Vol. 20 No. 4, pp. 199-210.

Gupta, A.K., Raj, S.P. and Wilemon, D. (1987), "Managing the R\&D-marketing interface", Research Management, Vol. 30 No. 2, pp. 38-43.

Gutmann, T. (2019), "Harmonising corporate venturing modes: an integrative review and research agenda”, Management Review Quarterly, Vol. 69, pp. 121-157, doi: 10.1007/s11301-018-0148-4.

Hair, J.F., Anderson, R.E., Tatham, R.L. and Black, W.C. (1998), Multivariate Data Analysis, 5th ed., Prentice Hall, Upper Saddle River, NJ.

Hair, J.F., Ringle, C.M. and Sarstedt, M. (2011), "PLS-SEM: indeed, a silver bullet”, Journal of Marketing Theory and Practice, Vol. 19 No. 2, pp. 139-152.

Hair, J.F., Ringle, C.M. and Sarstedt, M. (2012), "Partial least squares: the better approach to structural equation modelling?”, Long Range Planning, Vol. 45 Nos 5-6, pp. 312-319.

Hair, J.F., Matthews, L.M., Matthews, R.L. and Sarstedt, M. (2017), "PLS-SEM or CB-SEM: updated guidelines on which method to use", International Journal of Multivariate Data Analysis, Vol. 1 No. 2, pp. 107-123.

Helfat, C.E. and Peteraf, M.A. (2009), "The dynamic resources-based view”, Strategic Management Journal, Vol. 24 No. 10, pp. 997-1010.

Helfat, C.E. and Peteraf, M.A. (2015), "Managerial cognitive capabilities and the micro-foundations of dynamic capabilities", Strategic Management Journal, Vol. 36 No. 6, pp. 831-850.

Henseler, J., Dijkstra, T.K., Sarstedt, M., Ringle, C.M., Diamantopoulos, A., Straub, D.W., Ketchen, D.J., Hair, J.F., Hult, G.T.M. and Calantone, R.J. (2014), "Common beliefs and reality about partial least squares: comments on Rönkkö and Evermann (2013)", Organizational Research Methods, Vol. 17 No. 2, pp. 182-209.

Henseler, J., Ringle, C.M. and Sarstedt, M. (2015), “A new criterion for assessing discriminant validity in variance-based structural equation modelling”, Journal of the Academy of Marketing Science, Vol. 43 No. 1, pp. 115-135.

Hii, J. and Neely, A. (2000), "Innovative capacity of firms: on why some firms are more innovative than others", Proceedings of the 7th International Annual EurOMA Conference, Ghent, June 2000.

Hu, L.T. and Bentler, P.M. (1998), "Fit indices in covariance structure modelling: sensitivity to under parameterised model misspecification”, Psychological Methods, Vol. 3 No. 4, pp. 424-453.

Hung, R.Y.Y., Yang, B., Lien, B.Y.-H., McLean, G.N. and Kuo, Y.M. (2010), "Dynamic capabilities: impact of process alignment and organisational learning culture on performance", Journal of World Business, Vol. 45 No. 3, pp. 285-294. 
Janssen, M.J., Alexiev, A., Den Hertog, P. and Castaldi, C. (2012), "A multi-level multidimensional approach for measuring dynamic capabilities in service innovation management", Druid Conference, Copenhagen, pp. 1-24.

Janssen, M.J., Castaldi, C. and Alexiev, A. (2016), "Dynamic capabilities for service innovation: conceptualization and measurement”, R\&D Management, Vol. 46 No. 4, pp. 797-811.

Jantunen, A., Puumalainen, K., Saarenketo, S. and Heiko, K.K. (2005), "Entrepreneurial orientation, dynamic capabilities and international performance", Journal of International Entrepreneurship, Vol. 3 No. 3, pp. 223-243.

Karna, A., Richter, A. and Riesenkampff, E. (2015), "Revisiting the role of the environment in the capabilities: financial performance relationship: a meta-analysis", Strategic Management Journal, Vol. 37 No. 6, pp. 1154-1173.

Kitenga, G., Kilika, J.M. and Muchemi, A.W. (2020), "Dynamic capabilities and performance: the mediating role of firm competence", Journal of Economics and Business, Vol. 3 No. 1, pp. 450-474.

Kogut, B. and Zander, U. (1992), "Knowledge of the firm, combinative capabilities, and the replication of technology”, Organization Science, Vol. 3 No. 3, pp. 383-397.

Lawson, B. and Samson, D. (2001), "Developing innovation capability in organisations: a dynamic capabilities approach", International Journal of Innovation Management, Vol. 5 No. 3, pp. 377-400.

Li, D.Y. and Liu, J. (2014), "Dynamic capabilities, environmental dynamism, and competitive advantage: evidence from China”, Journal of Business Research, Vol. 67 No. 1, pp. 2793-2799.

Lichtenthaler, U. and Lichtenthaler, E. (2009), “A capability-based framework for open innovation: complementing absorptive capacity", Journal of Management Studies, Vol. 46 No. 8, pp. 1315-1338.

Macher, J.T. and Mowery, D.C. (2009), "Measuring dynamic capabilities: practices and performance in semiconductor manufacturing", British Journal of Management, Vol. 20, pp. S41-S62.

MacKenzie, S.B. and Podsakoff, P.M. (2012), "Common method bias in marketing: causes, mechanisms, and procedural remedies", Journal of Retailing, Vol. 88 No. 4, pp. 542-555.

Malik, O.R. and Kotabe, M. (2009), "Dynamic capabilities, government policies, and performance in firms from emerging economies: evidence from India and Pakistan”, Journal of Management Studies, Vol. 46 No. 3, pp. 421-450.

Mikalef, P. and Pateli, A. (2017), "Information technology-enabled dynamic capabilities and their indirect effect on competitive performance: findings from PLS-SEM and fsQCA", Journal of Business Research, Vol. 70, pp. 1-16.

Natalicchio, A., Petruzzelli, A.M. and Garavelli, A.C. (2014), "A literature review on markets for ideas: emerging characteristics and unanswered questions", Technovation, Vol. 34 No. 2, pp. 65-76.

Natalicchio, A., Petruzzelli, A.M. and Garavelli, A.C. (2017), "Innovation problems and search for solutions in crowdsourcing platforms-A simulation approach”, Technovation, Vol. 64, pp. 28-42.

Natalicchio, A., Petruzzelli, A.M., Cardinali, S. and Savino, T. (2018), "Open innovation and the human resource dimension”, Management Decision, Vol. 56 No. 6, pp. 1271-1284.

Petter, S., Straub, D. and Rai, A. (2007), "Specifying formative constructs in information systems research”, MIS Quarterly, Vol. 31 No. 4, pp. 623-656.

Podsakoff, P. and Organ, D. (1986), "Self-reports in organisational research: problems, and prospects", Journal of Management, Vol. 12 No. 4, pp. 531-544.

Podsakoff, P.M., MacKenzie, S.B., Lee, J.Y. and Podsakoff, N.P. (2003), "Common method biases in behavioural research: a critical review of the literature and recommended remedies", Journal of Applied Psychology, Vol. 88 No. 5, pp. 879-903.

Prange, C. and Verdier, S. (2011), "Dynamic capabilities, internationalisation processes and performance", Journal of World Business, Vol. 46 No. 1, pp. 126-133. capabilities and
competitive firm
performance

175 
EJIM

25,6

Protogerou, A., Caloghirou, Y. and Lioukas, S. (2012), "Dynamic capabilities and their indirect impact on firm performance”, Industrial and Corporate Change, Vol. 21 No. 3, pp. 615-647.

Randhawa, K., Wilden, R. and Hohberger, J. (2016), "A bibliometric review of open innovation: setting a research agenda”, Journal of Product Innovation Management, Vol. 33 No. 6, pp. 750-772.

Richard, O.C., Wu, P. and Chadwick, K. (2009), "The impact of entrepreneurial orientation on firm performance: the role of CEO position tenure and industry tenure", International Journal of Human Resource Management, Vol. 20 No. 5, pp. 1078-1095.

Rindskopf, D. and Rose, T. (1988), "Some theory and applications of confirmatory second-order factor analysis", Multivariate Behavioural Research, Vol. 23 No. 1, pp. 51-67.

Ringle, C.M., Sarstedt, M. and Straub, D.W. (2012), "Editor's comments: a critical look at the use of PLS-SEM in MIS Quarterly", MIS Quarterly, Vol. 36 No. 1, pp. iii-xiv.

Ringle, C.M., Wende, S. and Becker, J.M. (2015), “SmartPLS 3. Bönningstedt: SmartPLS”, available at: http://www.smartpls.com.

Ringov, D. (2017), "Dynamic capabilities and firm performance”, Long Range Planning, Vol. 50 No. 5, pp. 653-664.

Rothaermel, F.T. (2008), "Chapter 7: competitive advantage in technology intensive industries", in Libecap, G.D. and Thursby, M.C. (Eds), Technological Innovation: Generating Economic Results (Advances in the Study of Entrepreneurship, Innovation and Economic Growth), Vol. 18, Emerald Group Publishing, Bingley, pp. 201-225, doi: 10.1016/\$1048-4736(07)00007-0.

Schilke, O. (2014), "On the contingent value of dynamic capabilities for competitive advantage: the nonlinear moderating effect of environmental dynamism", Strategic Management Journal, Vol. 35 No. 2, pp. 179-203.

Schilke, O., Hu, S. and Helfat, C.E. (2018), "Quo vadis, dynamic capabilities? A content-analytic review of the current state of knowledge and recommendations for future research", Academy of Management Annals, Vol. 12 No. 1, pp. 390-439, doi: 10.5465/annals.2016.0014.

Simeone, L., Secundo, G., Messeni Petruzzelli, A. and Schiuma, G. (2020), "Design-based learning to enhance absorptive capacity for open innovation: the case of 3D Tune-In", Management Decision, Vol. 58 No. 9, pp. 1819-1839, doi: 10.1108/MD-10-2019-1448.

Teece, D.J. (2007), "Explicating dynamic capabilities: the nature and micro-foundations of (sustainable) enterprise performance”, Strategic Management Journal, Vol. 28 No. 13, pp. 1319-1350, doi: 10. 1002/smj.640.

Teece, D.J. (2012), "Dynamic capabilities: routines versus entrepreneurial action", Journal of Management Studies, Vol. 49 No. 8, pp. 1395-1401.

Teece, D.J. (2014), "A dynamic capabilities-based entrepreneurial theory of the multinational enterprise", Journal of International Business Studies, Vol. 45 No. 1, pp. 8-37.

Teece, D.J. (2018), "Dynamic capabilities as (workable) management systems theory", Journal of Management and Organization, Vol. 24 No. 3, pp. 359-368.

Teece, J.D. (2020), "Hand in glove: open innovation and the dynamic capabilities framework", Strategic Management Review, Vol. 1 No. 2, pp. 233-253, doi: 10.1561/111.00000010.

Teece, D.J., Pisano, G. and Shuen, A. (1997), "Dynamic capabilities and strategic management", Strategic Management Journal, Vol. 18 No. 7, pp. 509-533.

Teece, D.J., Peteraf, M. and Leih, S. (2016), "Dynamic capabilities and organizational agility: uncertainty and entrepreneurial management in the innovation economy"', California Management Review, Vol. 58 No. 4, pp. 13-25.

Teece, J.D., Raspin, P.G. and Cox, D.R. (2020), "Plotting strategy in a dynamic world", MIT Sloan Management Review, Vol. 62 No. 1, pp. 28-33.

Wang, K. (2015), "Determinants of mobile value-added service continuance: the mediating role of service experience", Information and Management, Vol. 55 No. 3, pp. 261-274. 
Wang, C.L. and Ahmed, P.K. (2007), "Dynamic capabilities: a review and research agenda", International Journal of Management Reviews, Vol. 9 No. 1, pp. 31-51.

Wang, C.H., Chang, C.H. and Shen, G.C. (2015a), "The effect of inbound open innovation on firm performance: evidence from high-tech industry", Technological Forecasting and Social Change, Vol. 99, pp. 222-230.

Wang, C.L., Senaratne, C. and Rafiq, M. (2015b), "Success traps, dynamic capabilities and firm performance", British Journal of Management, Vol. 26 No. 1, pp. 26-44.

Wilden, R., Devinney, T.M. and Dowling, G.R. (2016), "The architecture of dynamic capability research: identifying the building blocks of a configurational approach", Academy of Management Annals, Vol. 10 No. 1, pp. 997-1076.

Wu, L.Y. (2007), "Entrepreneurial resources, dynamic capabilities and start-up performance of Taiwan's high-tech firms", Journal of Business Research, Vol. 60 No. 5, pp. 549-555.

Zott, C. (2003), "Dynamic capabilities and the emergence of intra-industry differential firm performance: insights from a simulation study”, Strategic Management Journal, Vol. 24 No. 2, pp. 97-125.

\section{Further reading}

Abell, P., Felin, T. and Foss, N. (2008), "Building micro-foundations for the routines, capabilities, and performance links”, Managerial and Decision Economics, Vol. 29 No. 6, pp. 489-502.

Argote, L. and Ren, Y. (2012), "Transactive memory systems: a micro-foundation of dynamic capabilities", Journal of Management Studies, Vol. 49 No. 8, pp. 1375-1382.

Chesbrough, H. (2006), Open Business Models: How to Thrive in the New Innovation Landscape, Harvard Business School Press, Boston, MA.

Chesbrough, H., Heaton, S. and Liang, M. (2018), "Open innovation with Chinese characteristics: a dynamic capabilities perspective", working paper, Haas Business School, Berkeley, CA.

Foss, N.J. and Lindenberg, S. (2013), "Micro-foundations for strategy: a goal-framing perspective on the drivers of value creation", Academy of Management Perspectives, Vol. 27 No. 2, pp. 85-102.

Hodgkinson, G.P. and Healey, M.P. (2011), "Psychological foundations of dynamic capabilities: reflexion and reflection in strategic management", Strategic Management Journal, Vol. 32 No. 13 , pp. 1500-1516.

Lindenberg, S. and Foss, N.J. (2011), "Managing joint production motivation: the role of goal framing and governance mechanisms", Academy of Management Review, Vol. 36 No. 3, pp. 500-525.

Wilden, R. and Gudergan, S. (2017), "Service-dominant orientation, dynamic capabilities and firm performance", Journal of Service Theory and Practice, Vol. 27 No. 4, pp. 808-832.

\section{Corresponding author}

Shahrokh Nikou can be contacted at: shahrokh.nikou@abo.fi
Dynamic capabilities and competitive firm performance 